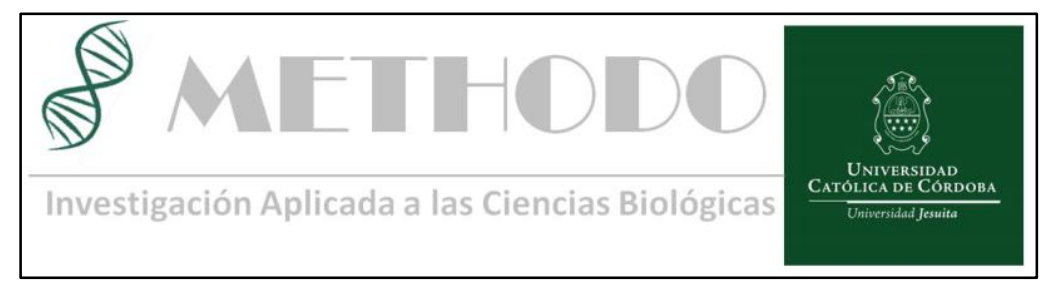

ARTICULO ORIGINAL Methodo 2017; 2(1):25-28 DOI: $10.22529 / \mathrm{me} .2017 .2(1) 06$

\title{
Morbilidad Respiratoria en Prematuros Tardíos y Término Tempranos *
}

\section{Respiratory morbidity in late preterm and early term infant *}

${ }^{*}$ Resumen de Trabajo Presentado en las XIII Jornadas de Investigación de la Clínica Universitaria Reina Fabiola- Diciembre de 2016

Ceballos $\mathrm{E}^{1}$, Maure $\mathrm{CP}^{1}$, Sosa $\mathrm{IA}^{1}$, Wainzstein $\mathrm{D}^{1}$, Dipietro $\mathrm{D}^{1}$, Burgos $\mathrm{V}^{1}$, Cavallero $\mathrm{N}^{1}$

\section{RESUMEN} Introducción:

Los Recién Nacidos prematuros tardíos (RNPTT) y los Recién Nacidos de Término Temprano (RNTt) son considerados una población de riesgo, con altos índices de ingreso hospitalario y morbimortalidad, mayor cantidad de días de internación y altas tasas de reingreso hospitalario en comparación a los Recién Nacidos de Término Tardío (RNTT). El Síndrome de distrés respiratorio es uno de los principales diagnósticos al ingreso, requiriendo distintos modos de soporte respiratorio, por lo tanto, requieren de cuidados especiales en unidades de media o alta complejidad, significando así un importante costo en salud.

\section{Objetivos:}

Comparar la frecuencia en que se presenta la morbilidad respiratoria (MR) entre RNPTT y en RNTt Vs Recién Nacido a Termino Tardío (RNTT). Establecer factores asociados a MR. Describir los distintos modos de soporte respiratorio utilizados.

\section{Pacientes y Métodos:}

Se incluyeron a todos los RNPTT (34 a 36 SEG), y RNTt (37 a 38 SEG) y se compararon con todos los pacientes RNTT (39 a 41 SEG) durante los años 2011 a 2015. Se excluyó a pacientes con malformación o síndrome genético, o derivados de otro centro médico.

\section{Análisis estadístico:}

La frecuencia de MR se consignó en porcentajes. La misma se comparó en ambos grupos utilizando la prueba de Chicuadrado y se realizó el cálculo de Odss Ratio. Las variables maternas o neonatales asociadas a MR se compararon entre los pacientes con o sin MR utilizando prueba $U$ de Mann-Whitney para las variables continuas y Chi-cuadrado para variables categóricas. Las variables con un valor de $P \leq 0.1$ en el análisis univariado se incluyeron en un modelo multivariado de regresión logística. El soporte terapéutico 
Ceballos E, Maure CP, Sosa IA, Wainzstein D et al

Morbilidad Respiratoria en Prematuros Tardíos y Término Tempranos

utilizado fue descripto en porcentajes y

nacer con Apgar menor a 7 a los 5 min y la

comparados mediante prueba de Chi-

existencia de patología materna asociada

cuadrado y evaluados mediante odss ratio.

\section{Resultados:}

Durante el periodo evaluado se analizaron

los datos de 10512 pacientes de los cuales

766 (7,8\%) fueron RNPTT, 3654 (92,6\%)

RNTt y 6087 (57,90\%) RNTT. La

frecuencia de MR en los RNPTT fue de

202 (26,4\%), en los RNTt fue de 115

$(3,15 \%)$ Vs $46(0,76 \%)$ en los RNTT. El

Odss ratio para MR entre RNPTT y RNTt

comparado con RNTT respectivamente fue:

OR 47.03, IC95\% 33.7 a 65.53, P 0.0001,

OR 4.26, IC95\% 3.02 a 6.02, P 0.0001.

(Siendo los RNTT el grupo control. Ver

tabla). En el análisis multivariado se

observaron factores de riesgo asociados a

MR: Patología asociada al embarazo (OR

4,248, IC95\% 2,918 a 6,184, P 0.0001), el

Apgar menor a 7 a los 5 min (OR 15,09,

IC95\% 4,64 a 49,03, P 0.0001), el

nacimiento por cesárea (OR 2,96 IC95\%

2,32 a 3,78, P 0.0001), sexo masculino (OR

1,5 IC95\% 1,21 a 2,01, 0,001). En la

evaluación en toda la población general se

observó al Retardo de Crecimiento

Intrauterino (RCIU) como factor protector

de MR, (OR 0.51, IC95\% 0,29 a 0,92, P

0.029). Los datos en relación al soporte de

oxígeno se muestran en la Tabla1.

\section{Conclusión:}

Los recién nacidos prematuros tardíos y

los recién nacido termino temprano

presentaron mayor morbilidad respiratoria

comparado con los recién nacidos termino

tardío. Los factores de riesgo más

preponderantes para MR fueron la

prematurez, el nacimiento por cesárea,

Revista Methodo: Investigación Aplicada a las Ciencias Biológicas. Facultad de Medicina. Universidad 
Ceballos E, Maure CP, Sosa IA, Wainzstein D et al

Morbilidad Respiratoria en Prematuros Tardíos y Término Tempranos

LTN (39-41 SEGs) during the years 2011 to and Male sex (OR 1,5 IC95\% 1,21 a 2,01

2015. Were excluded patients With malformation or genetic syndrome, or derived from another medical center.

\section{Statistical analysis:}

The frequency of RM was recorded in percentages. The same was compared in both groups using the Chi-square test and the Odss Ratio calculation was performed. Maternal or neonatal variables associated with RM were compared between patients with or without RM using Mann-Whitney U test for continuous variables and Chisquare for categorical variables. Variables with a value of $P \leq 0.1$ in the univariate analysis were included in a multivariate logistic regression model. The therapeutic support used was described in percentages and compared by chi-square test and evaluated by odss ratio.

\section{Results:}

Data from 10512 patients were analyzed in the evaluation periode, of which $766(7.8 \%)$ were LPN, 3654 (92.6\%) ETN and 6087 $(57.90 \%)$ LTN. The frequency of RM in the LPN was 202 (26.4\%), in the ETN it was $115(3.15 \%)$ vs $46(0.76 \%)$ in the LTN, the odss ratio for RM comparing LPN and ETN with LTN respectively was: OR 47.03, 95\%

Cl 33.7 to 65.53, P 0.0001, OR 4.26, IC95\% 3.02 to 6.02, P 0.0001 (LTN being the control group. See table). In the multivariate analysis it was observed the risk factors asociated with RM: the pathology associated with pregnancy (OR 4.248, 95\% Cl 2.918 to 6.184, P 0.0001), Apgar less than 7 at 5 min (OR 15.09, 95\% Cl 4.64 to 49.03, P 0.0001). Cesarean birth (OR 2.96, IC95\% 2.32 a 3.78, P 0.0001 )

$P 0,001)$. In the evaluation in the general population, the Intrauterine Growth

Retardation (IUGR) was observed as a protective factor of MR, (OR 0.51, 95\% Cl 0.29 to 0.92 , P 0.029). The data in relation to the oxygen support are shown in Table 1.

\section{Conclusion:}

Late preterm infants and early term infants presented higher respiratory morbidity compared to late term newborns. The most important risk factors for RM were prematurity, cesarean birth, birth with Apgar less than 7 at 5 minutes and the existence of maternal pathology associated with pregnancy. The LPN and ETN are a population at risk (greater requirement of hospitalization, more days of hospitalization, greater respiratory morbidity and greater support of oxygen), so that preventive actions must be taken to reduce the risk factors who give late preterm and early term birth and thus reduce morbidity rates and health costs that these imply.

\section{Palabras claves: RECIÉN NACIDOS DE TÉRMINO TARDÍO, SÍNDROME DE DISTRÉS RESPIRATORIO, SOPORTE RESPIRATORIO,}

\section{Keywords: LATE TERM NEWBORNS, RESPIRATORY DISTRESS, RESPIRATORY SUPPORT}

\footnotetext{
${ }^{1}$ Universidad Católica de Córdoba, Argentina. Clínica Universitaria Reina Fabiola, Servicio de Neonatología. Correspondencia: Esteban Ceballos , Servicio de Neonatología - Clínica Universitaria Reina Fabiola. Oncativo 1248 -X5004FHP- Córdoba, Argentina. email: estebanceballos1@gmail.com
} 


\begin{tabular}{|c|c|c|}
\hline 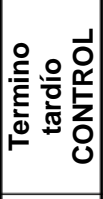 & 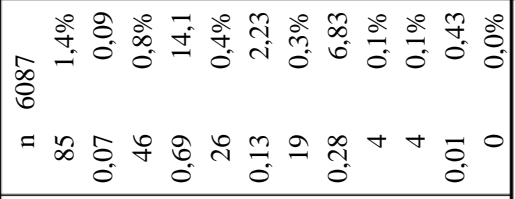 & \\
\hline 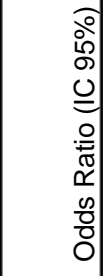 & 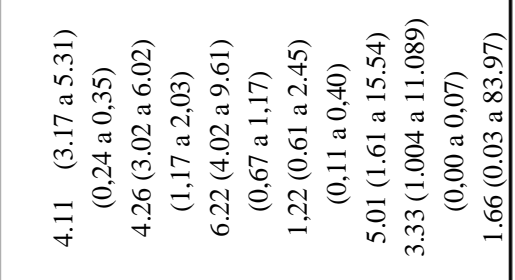 & 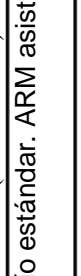 \\
\hline 2 & 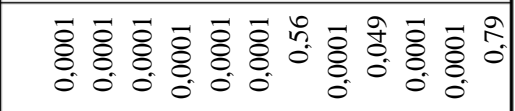 & 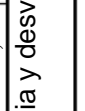 \\
\hline 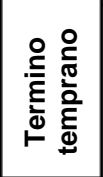 & 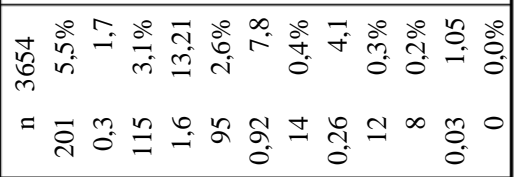 & 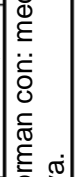 \\
\hline 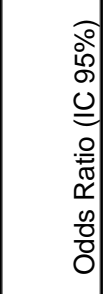 & 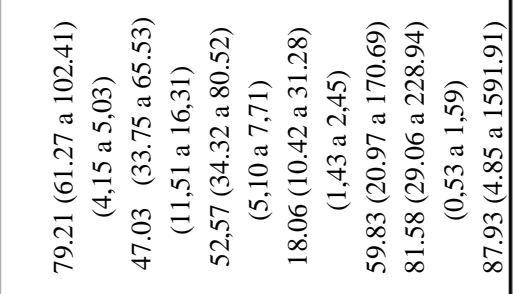 & 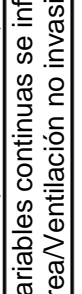 \\
\hline 0 & 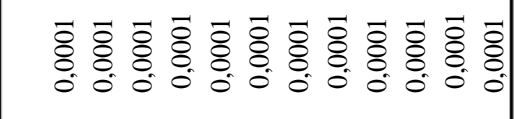 & 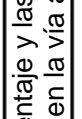 \\
\hline 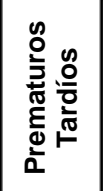 & 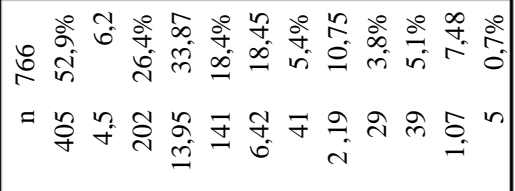 & 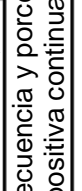 \\
\hline 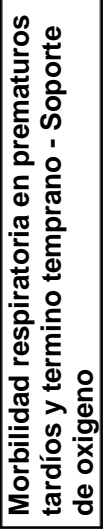 & 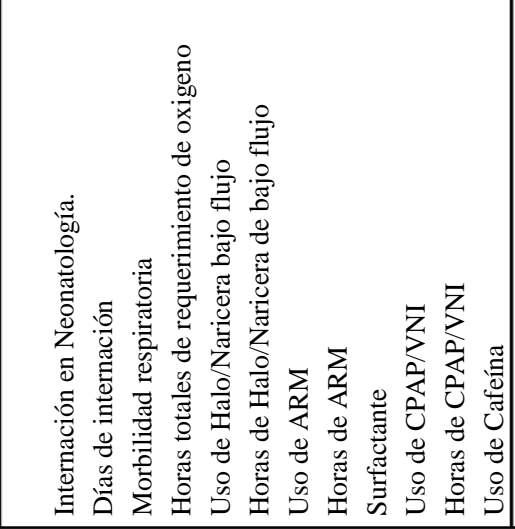 & 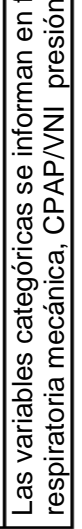 \\
\hline
\end{tabular}

\section{(C) (1)(®)}

